УДК 536.248.2

\title{
ЕНЕРГОЗБЕРІГАЮЧІ ТЕХНОЛОГІЇ ФОРМУВАННЯ ОБ'ЄМНИХ АМОРФНИХ СТРУКТУР
}

\author{
А.М. Павленко, Б.О. Усенко, А.В. Кошлак \\ Полтавський національний технічний університет імені Юрія Кондратюка (Полтава, \\ Україна)
}

\section{ЭНЕРГОСБЕРИГАЮЩИЕ ТЕХНОЛОГИИ ФОРМИРОВАНИЯ ОБЬЕМНЫХ АМОРФНЫХ СТРУКТУР}

\author{
А.Н. Павленко, Б.О. Усенко, А.В. Кошлак \\ Полтавский национальный технический университет имени Юрия Кондратюка \\ (Полтава, Украина)
}

\section{ENERGOSBERIGAYUSCHIE TECHNOLOGY OF FORMATION OF BULK AMORPHOUS STRUCTURE.}

AN Pavlenko, BO Usenko AV Koshlakov.

Poltava National Technical University named after Yuri Kondratyuk (Poltava, Ukraine).

В статті наведено результати експериментального дослідження енергозберігаючих технологій формування об'ємних аморфних сплавів. Розглянуті методи математичного моделювання та оптимізації процесу отримання об'ємних аморфних структур, які дозволяють скоротити час експериментальних досліджень та матеріальні ресурси для створення високоефективного виробництва аморфних сплавів. Результати фізичних експериментів порівнюються з результатами розрахунку. Отримані результати можуть бути використані для аналізу фізичних закономірностей та обгрунтованого вибору технологічних режимів формування аморфних структур

Ключові слова: енергозбереження, аморфна структура, теплопровідність, математична модель, охолодження.

В статье приведены результаты экспериментального исследования энергосберегающих технологий формирования объемных аморфных сплавов. Рассмотрены методы математического моделирования и оптимизации процесса получения объемных аморфных 
структур, которые позволяют сократить время экспериментальных исследований и материальные ресурсы для создания высокоэффективного производства аморфных сплавов. Результаты физических экспериментов сравниваются с результатами расчёта. Полученные результаты могут быть использованы для анализа физических закономерностей и обоснованного выбора технологических режимов формирования аморфных структур.

Ключевые слова: энергосбереженя, аморфная структура, теплопроводность, математическая модель, охлаждение.

In article results of experimental research energy-saving technologies of formation of volume amorphous alloys. The investigations of casting technology in cooled form is time-consuming, which allows to reduce the use of methods of mathematical modeling and optimization. The methods of mathematical modeling and optimization of the process obtaining volume amorphous structures, which can reduce experimental studies and material resources for create a highly efficient production of amorphous alloys. The use of modern methods of mathematical modeling allows us to solve complex problems of heat transfer, to investigate the features of the technological process, identify the qualitative picture of the interaction of various factors. There is a possibility by means of calculation to establish quantitative functional relationships.

The results provide an effective assessment of the intensity of heat transfer during the casting process, which makes it possible to estimate and predict the ability of alloys to the amorphization of the structure.

The results of physical experiments are compared with the results of the calculation. The results can be used to analyze the physical regularities and informed choice of technological modes of formation of amorphous structures.

Keywords: energy efficiency, amorphous structure, thermal conductivity, a mathematical model of cooling.

\section{Вступ}

Формування аморфної структури металів та сплавів призводить до фундаментальних змін магнітних, електричних, механічних, надпровідних та інших властивостей. Сплави 3 аморфною структурою мають високу твердість, міцність, в'язкість руйнування, корозійну стійкість, зносостійкість. Всі перераховані вище властивості роблять аморфні сплави ідеальними енергозберігаючими матеріалами для застосування в області теплоенергетичних технологій та теплоенергетичних установок.

Процес формування масивного шару 3 аморфною структурою має ряд проблем, так як охолодження об'ємного масиву розплавленого металу, на відміну від тонких плівок $€$ процесом, який відрізняється значною інтенсивністю енергообмінних процесів. Для отримання масивних аморфних структур нами була розроблена експериментальна лабораторна установка, на якій досліджували процес отримання масивних аморфних структур методом розливання в мідну охолоджуючу форму 3 наступним швидкісним охолодженням.

\section{Теоретична частина}

Для можливості отримання аморфної структури в чистих металах швидкість охолодження розплаву повинна бути не нижче $10^{6} \mathrm{~K} / \mathrm{c}$, що досить складно забезпечити при даній технології.

В якості досліджуваних були обрані сплави 3 добавками, які збільшують схильність рідких сплавів до об'ємної аморфізації. Сплави $\mathrm{Cu}_{45} \mathrm{Ti}_{35} \mathrm{Zr}_{20}, \mathrm{Ni}_{62,4} \mathrm{Nb}_{37,6}$, $\mathrm{Fe}_{80} \mathrm{P}_{13} \mathrm{C}_{7}, \mathrm{Co}_{75} \mathrm{Si}_{15} \mathrm{~B}_{10}$ які були виготовлені 3 порошкових компонентів. Для виготовлення сплавів використовувались чисті шихтові матеріали. Досліджувані сплави були виплавлені в індукційній високочастотної печі в атмосфері аргону методом прямого сплавлення компонентів. Після отримання однорідного розплаву через отвір в днищі тигля розплав виливається в охолоджувану мідну форму. Хімічний склад основних компонентів сплаву контролювався 
мікрорентгеноспектральним аналізом точністю до \pm 1 ат \% і локальністю 1,0 мкм.

Процес отримання масивного шару металу 3 аморфною структурою виконували способом розливання в форму, що охолоджується водою в процесі активного тепловідведення тепло буде витрачатися на випаровування води, що знаходиться біля контактної поверхні, в такому випадку можна розглядати 3 режими охолодження [1].

У першому випадку швидкість руху води має малі значення i в процесі охолодження утворюється паровий шар, що огортає теплопровідну поверхню. У цьому випадку поверхня 3 боку води покривається паром, створюючи термоопір тепловому потоку.

У другому випадку при збільшенні швидкості руху охолоджуючої води парова фаза у теплообмінної поверхні буде схильна до руйнування, що призводить до підвищення інтенсивності тепловідведення.

$$
\text { У третьому випадку при }
$$
турбулентному режимі течії масова витрата води має максимальне значення, i відсоток парової фази матиме мінімальне значення, вода буде виштовхувати пар i швидкість охолодження в цьому випадку буде мати максимальні значення.

Таким чином, змінюючи витрату води в установці, поступово збільшуючи швидкість руху охолоджуючої води у теплообмінної стінки можна управляти щільністю теплового потоку на охолоджуваній зовнішній поверхні форми і, відповідно процесом затвердіння.

Затвердіння злитка відбувається в результаті відведення теплоти перегріву рідкого металу i прихованої теплоти затвердіння від злитка в охолоджувану форму і далі в навколишнє середовище [1].

Для вивчення структури i визначення ступеня аморфізації вирізали кілька зразків (темплетів) таким чином, щоб можна було визначити зміну структури по ряду поперечних перерізів. Для виявлення мікроструктури проводилося хімічне травлення 3 використанням реактиву, що складається $3 \mathrm{CH}_{3}-\mathrm{COOH}, \mathrm{HNO}_{3}$ i $\mathrm{HF}$. Для визначення ступеня аморфізації проводили електронно-макроскопічні дослідження в режимі прямого розширення. Для візуального перегляду зразків i фотографування застосовували мікроскоп MMP-4 [1].

Металофізичними дослідженнями було встановлено, що досліджуваний шар металу, отриманий методом лиття в охолоджувану форму в першому випадку рис.1 має кристалічну ферито-перлітну структуру, утворення аморфної структури не відбулося, оскільки швидкість руху охолоджуючої води мала значення менше $1 \mathrm{~m} / \mathrm{c}$, при максимальній температурі води $15{ }^{\circ} \mathrm{C}$ i максимальній товщині шару металу.

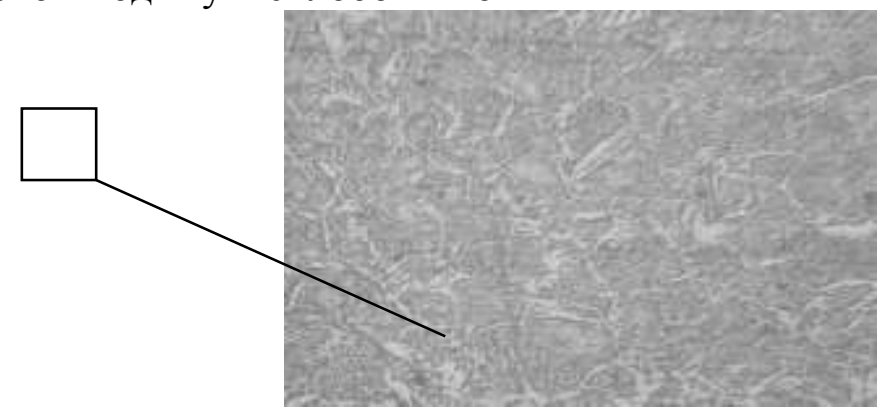

Рис.1 - Кристалічна структура масивного шару металу

Досліджуваний шар металу в другому випадку рис.2 частково має аморфну структуру по межах шару, поблизу кордону 3 охолоджуючим середовищем, а в середині мікрокристалічну ферито-перлітну структуру, крім фериту та перліту присутні так само мартенсит, бейніт і залишковий аустеніт. Формування аморфної структури по межах шару відбулося в результаті збільшення швидкості руху охолоджуючої води до $2 \mathrm{~m} / \mathrm{c}$ і зменшенні температури води до $7^{\circ} \mathrm{C}$ при середніх значеннях товщини шару металу. 


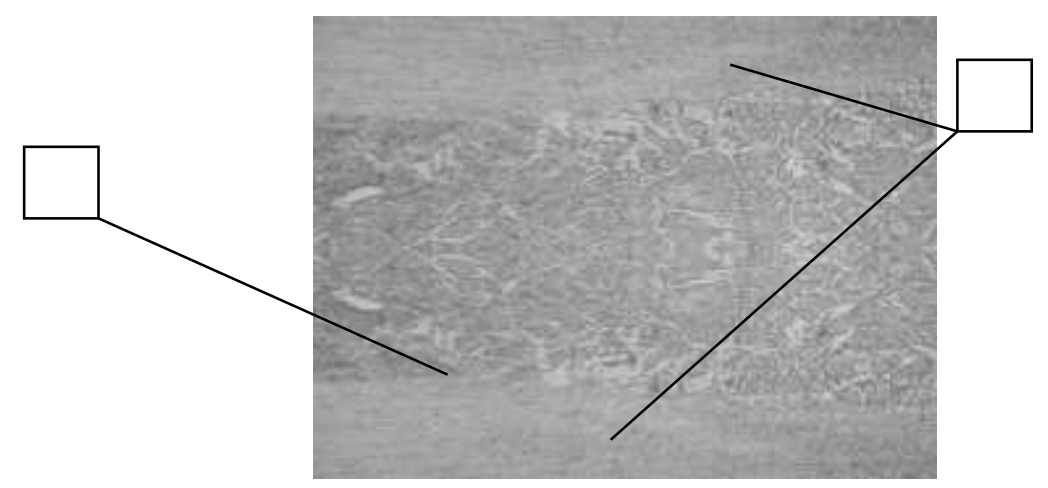

А - аморфная структура, $\mathrm{K}$ - кристалічна

Рис.2 - Аморфно-кристалічна структура масивного шару металу

У третьому випадку рис.3 при турбулентному режимі течії досліджуваний шар металу частково має аморфну структуру по межах шару, поблизу кордону 3 охолоджуючим середовищем, а в середині злитка мікрокристалічну ферито-перлітну структуру отриману при максимальній швидкості руху води 3 м/с, мінімальній температурі води $5{ }^{\circ} \mathrm{C}$ і товщині шару металу 5 мм. Так як швидкість охолодження в цьому випадку буде мати максимальні значення, спостерігали збільшення аморфної фази металу.

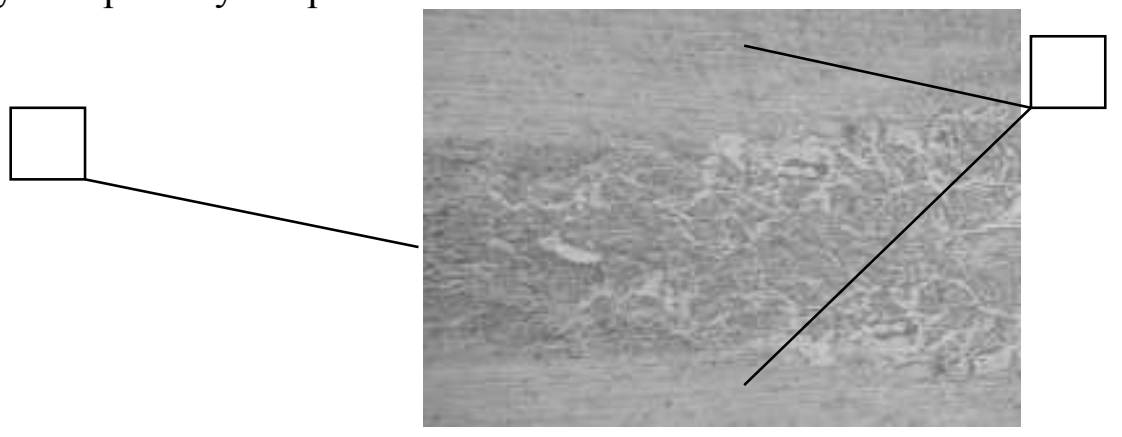

А - аморфная структура, $\mathrm{K}$ - кристалічна

Рис.3 - Аморфно-кристалічна структура масивного шару металу, отримана при підвищеній швидкості охолодження

Виходячи 3

результатів експериментальних досліджень формування масивного шару 3 аморфною структурою можна досягти при мінімальних значеннях температури охолоджуючої води i максимальній швидкості руху охолоджуючої води, але основним фактором виступає значення товщини шару металу.

Термічна стійкість аморфних сплавів i процес затвердіння вивчали за допомогою диференціального скануючого калориметра Setaram DSC 131. Для обробки термограм використовували пакет програм, що входять в комплект калориметра. Обробку експериментальних даних проводили в програмному пакеті для статистичного аналізу StatSoft Statistica 6.0 рис.4-5.

Максимальна степінь охолодження досягається у поверхонь шару, що примикають до охолоджуваних стінок форми, при максимальній швидкості руху охолоджуючої води у теплообмінних стінок форми i мінімальній температурі охолоджуючої води (рис.4-5), але все ж головним чинником який має найбільший вплив на степінь аморфізації виступає товщина розплаву. Температура кристалізації всередині шару вище, ніж у поверхонь шару. Тривалість процесу охолодження всередині шару в 5-10 разів більше [2]. 
За допомогою металофізичних досліджень було зафіксовано, що деякі "аморфні" фази, що знаходяться всередині шару складаються 3 мікрокристалів, що в свою чергу доводить псевдоаморфність цих фаз.

Експериментальні

дослідження технології лиття в охолоджувану форму вимагає великих витрат часу і матеріальних ресурсів, скоротити які дозволяе застосування методів математичного моделювання та оптимізації.

Використовуючи сучасні методи та засоби математичного моделювання, можна вирішувати складні завдання теплопередачі, а так само досліджувати особливості технологічного процесу, виявляти якісну картину взаємодії різних факторів. Існує можливість розрахунковим шляхом встановити кількісні функціональні залежності [2].

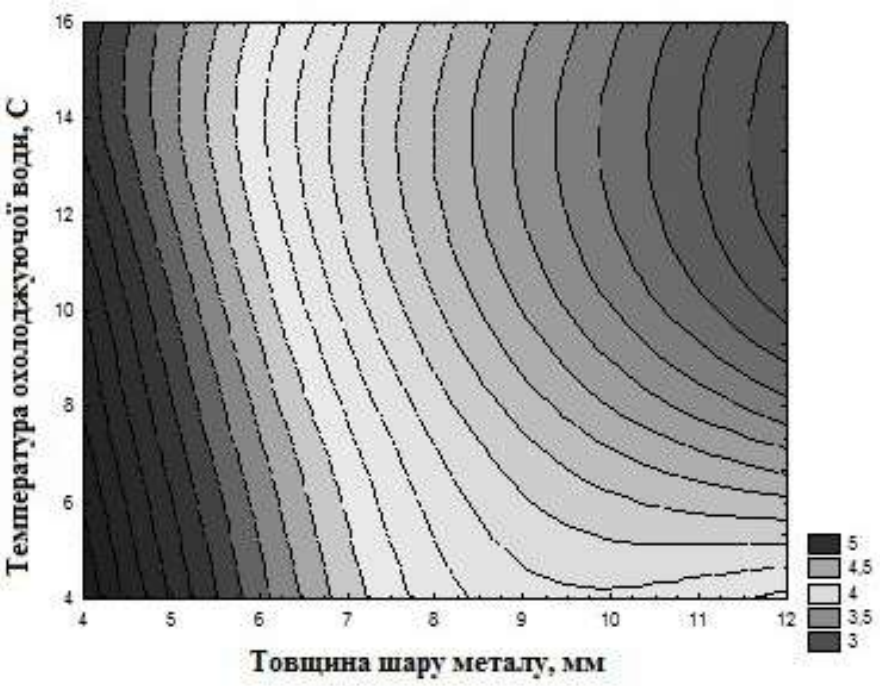

Рис.4 - Графік залежності степені аморфізації від температури охолоджуючої води та товщини шару металу

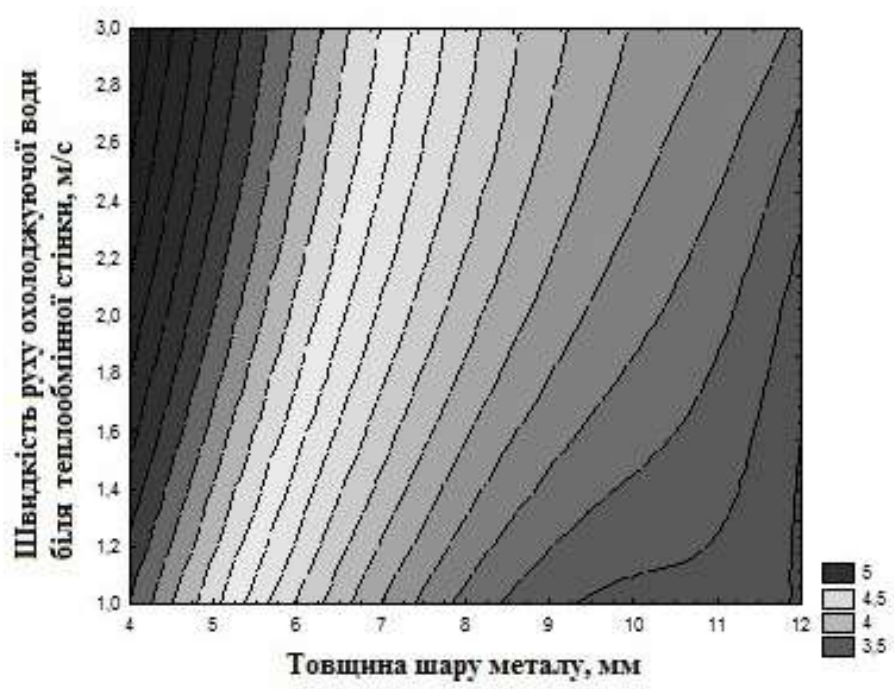

Рис.5 - Графік залежності степені аморфізації від швидкості руху охолоджуючої води біля теплообмінної стінки та товщини шару металу

Математичне формулювання задачі відповідних крайових умовах. Перший крок лиття металу в охолоджувану форму починається 3 задавання виду і розмірності включає рівняння теплопровідності, що моделі (1D, 2D, або 3D) [3]. 
При розгляді спільного вирішення моделі загальної теплопередачі і моделі слабко стисливої рідини Нав'є-Стокса в стартовому меню слід вибрати 2D (General heat transfer) та 2D задачу (Weakly Compressible Navier-Stokes). Побудована за вищевказаним алгоритмом модель процесу лиття металу в охолоджувану форму дає графічне рішення, на якому ми можемо бачити розподіл температур (температурне поле), напрямок ліній струму, градієнт температур.

Таким чином, розподіл температури в злитку, що твердне визначається рішенням системи рівнянь (1) - (2) 3 відповідними крайовими умовами [3].

Для вирішення цих рівнянь необхідно сформулювати початкові і граничні умови, тобто розподіл температур в початковий момент і умови теплообміну з навколишнім середовищем.

Необхідною умовою вирішення рівнянь $\epsilon$ знання теплофізичних властивостей металів і сплавів при високих температурах: теплоємності, теплопровідності і теплоти затвердіння (стеклування).

$$
\rho C_{\rho} \frac{\partial T}{\partial t}+\nabla(-k \nabla T)=Q+q_{s} T
$$

де $q_{s}$ - коефіцієнт поглинання, Вт/м ${ }^{3} \cdot \mathrm{K}$

$Q$ - джерело тепла, Вт/м ${ }^{3}$

$k$ - коефіцієнт теплопровідності, Вт/м $\cdot \mathrm{K}$

$T$ - температура, $\mathrm{K}$

$\rho$ - густина, кг $/ \mathrm{M}^{3}$

$C_{p}$ - теплоємність при постійному тиску, Дж/кг·К

$\nabla$ - Опера́тор На́бла;

Рівняння Нав'є-Стокса

$$
\begin{aligned}
& \rho \frac{\partial u}{\partial t}+\rho(u \nabla) u=\nabla\left[-p I+\mu\left(\nabla u+(\nabla u)^{T}\right)-\frac{2}{3} \mu(\nabla u) I\right]+F \\
& \frac{\partial \rho}{\partial t}+\nabla(\rho u)=0
\end{aligned}
$$

$$
\begin{aligned}
& \rho \text { - густина, кг/м }{ }^{3} \\
& \eta \text { - динамічна в'язкість, Па·с } \\
& k_{d v} \text { - об'ємна в'язкість, Па·с } \\
& u \text { - швидкість, м/с. }
\end{aligned}
$$

В якості модельного сплаву був обраний сплав, що володіє гарною схильністю до аморфізації, внаслідок вмісту в складі сплаву легко-аморфізуємих елементів, таких як цирконій $\mathrm{Zr}$.

3 попередніх досліджень відомо, що товщина розплаву, при формуванні аморфної структури значно впливає на властивості i структуру металів і сплавів. Виходячи 3 цього, в якості досліджуваних, були обрані дві охолоджувані форми 3 різними розмірами, що в свою чергу визначало товщину розплаву і можливість отримання аморфної структури. У табл.1 наведені теплофізичні властивості досліджуваного сплаву. 
Таблиця 1. Теплофізичні властивості досліджуваного сплаву

\begin{tabular}{|c|c|c|c|c|c|}
\hline 丞 & 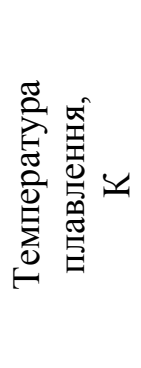 & 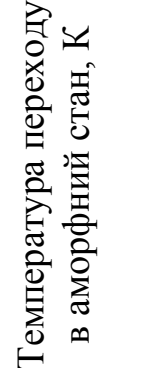 & 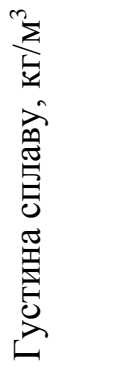 & 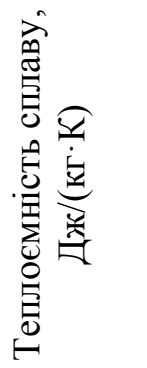 & 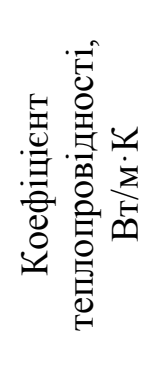 \\
\hline $\mathrm{Cu}_{45} \mathrm{Ti}_{35} \mathrm{Zr}_{20}$ & 1063 & 683 & 6900 & 385 & 340 \\
\hline
\end{tabular}

Сплав системи $\mathrm{Cu}_{45} \mathrm{Ti}_{35} \mathrm{Zr}_{20}$ від інших масивних аморфних сплавів відрізняється високою твердістю, міцністю та термічною стабільністю. При збільшенні вмісту $\mathrm{Zr}$ до $18 \%$ термічна стабільність сплаву зростає 3 690К до 815 К, що істотно збільшує область застосування даного виду сплавів. Формування аморфної структури цього сплаву досить неоднозначний процес. Умови для вирішення теплової задачі лиття сплаву $\mathrm{Cu}_{45} \mathrm{Ti}_{35} \mathrm{Zr}_{20}$ наведені в табл.2. Результати моделювання у вигляді графіків і полів розподілу температур наведені на рис.6-11. Отримані графіки дають ефективну оцінку інтенсивності тепловіддачі під час процесу лиття, що дає можливість оцінити і прогнозувати здатність сплавів до аморфізації структури.

Таблиця 2. Параметри для вирішення теплової задачі лиття сплаву $\mathrm{Cu}_{45} \mathrm{Ti}_{35} \mathrm{Zr}_{20}$

\begin{tabular}{|c|c|}
\hline Назва параметра & Значення параметра \\
\hline $\begin{array}{ll} & \text { Температура розплаву перед процесом } \\
\text { лиття } & \end{array}$ & T_in $=1063 \mathrm{~K}$ \\
\hline $\begin{array}{l}\text { Температура на стінках охолоджуваної } \\
\text { форми }\end{array}$ & $T_{-} \mathrm{K}=373,673 \mathrm{~K}$ \\
\hline Швидкість лиття & $\mathrm{v}$ cast $=1,6 \mathrm{MM} / \mathrm{c}$ \\
\hline Густина розплаву & $\rho=6900 \mathrm{\kappa} \Gamma / \mathrm{M}^{3}$ \\
\hline Питома теплоємність металу & $\mathrm{C} \rho=385$ Дж/(кг·К $)$ \\
\hline Динамічна в’язкість & $\eta=0,0434$ Па $\cdot c$ \\
\hline Приховане тепло & $\mathrm{dH}=205$ кДж/кГ \\
\hline Коефіцієнт теплопровідності & $\mathrm{k}=340 \mathrm{BT} / \mathrm{M} \cdot \mathrm{K}$ \\
\hline Інтервал виміру процесу лиття & $0-1$ сек \\
\hline $\begin{array}{l}\text { Розмір форми (товщина виливки): висота } \\
\times \text { діаметр, }\end{array}$ & $100 \times 3,100 \times 10$ \\
\hline
\end{tabular}



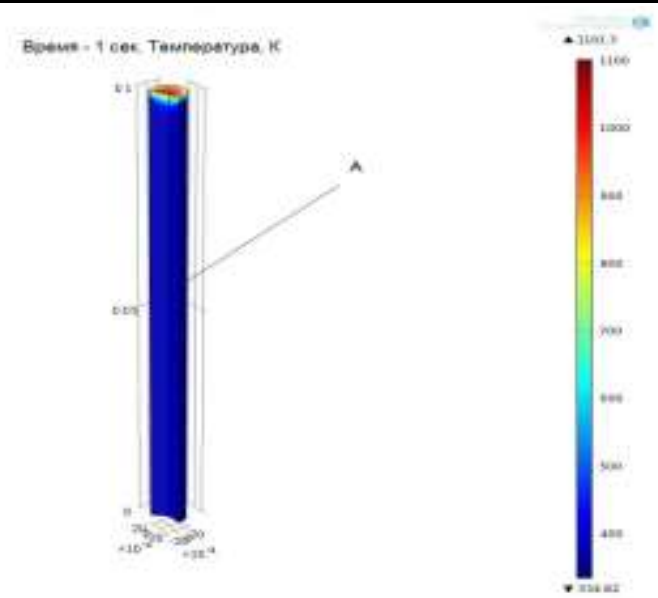

А - аморфна структура

Рис.6 - Температурне поле розплаву $\mathrm{Cu}_{45} \mathrm{Ti}_{35} \mathrm{Zr}_{20}$ в охолоджуваній формі

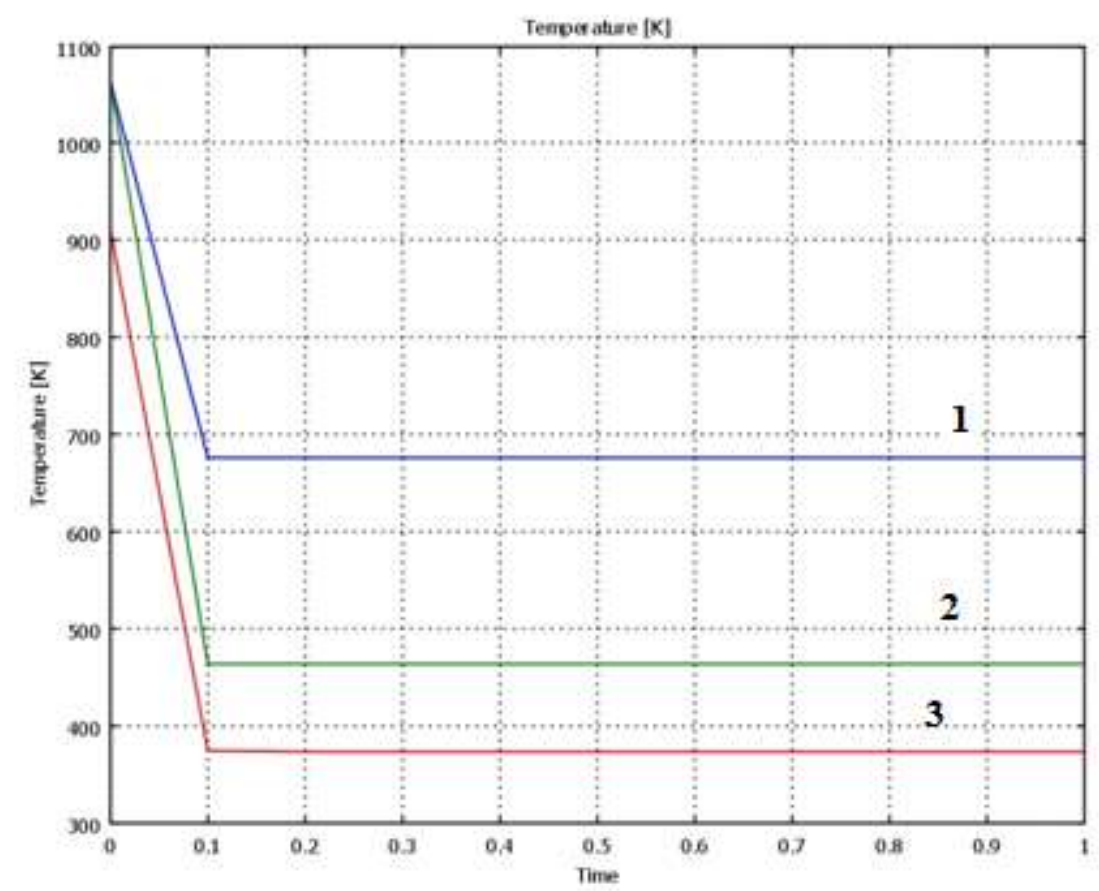

Рис. 7 - Розподіл температури в сплаві $\mathrm{Cu}_{45} \mathrm{Ti}_{35} \mathrm{Zr}_{20}$ при температурі на стінках форми $373 \mathrm{~K}$

1 - центр литво, 2 - поблизу охолоджуваної стінки форми, 3 - поблизу кордону 3 охолоджувальним середовищем. 


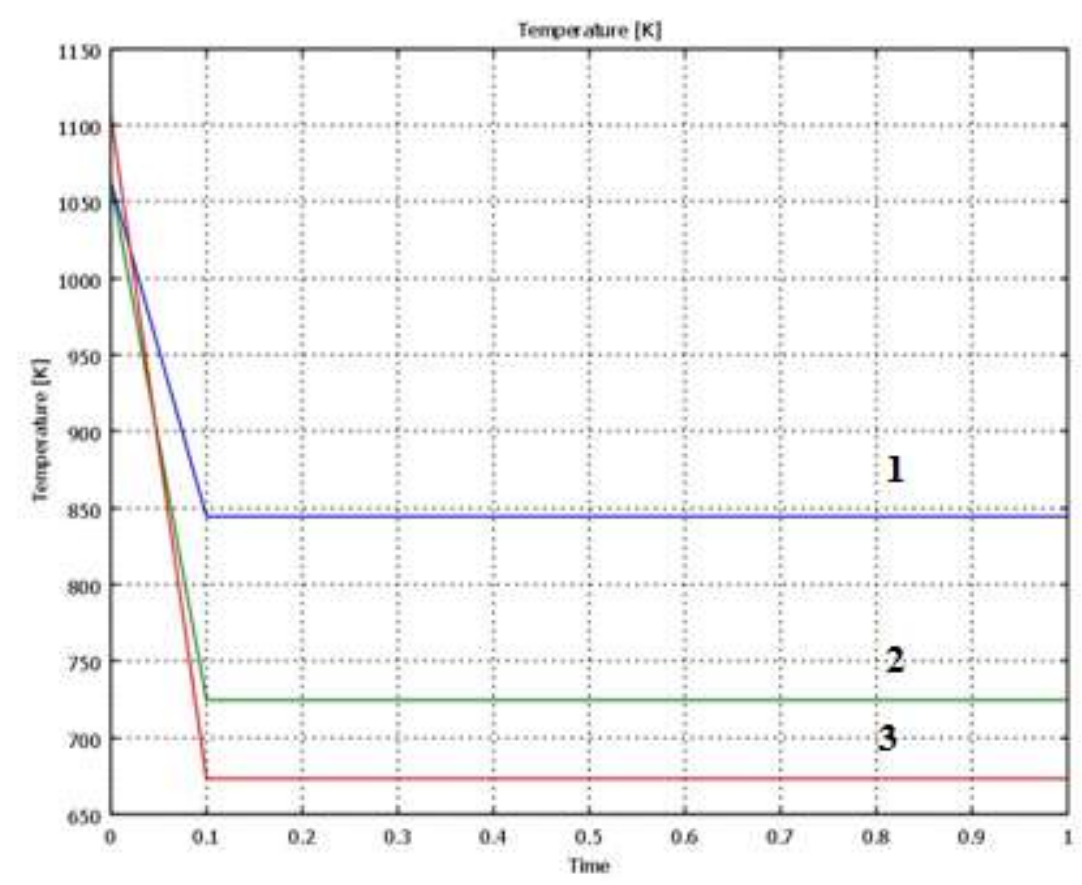

Рис. 8 - Розподіл температури в сплаві $\mathrm{Cu}_{45} \mathrm{Ti}_{35} \mathrm{Zr}_{20}$ при температурі на стінках форми $673 \mathrm{~K}$

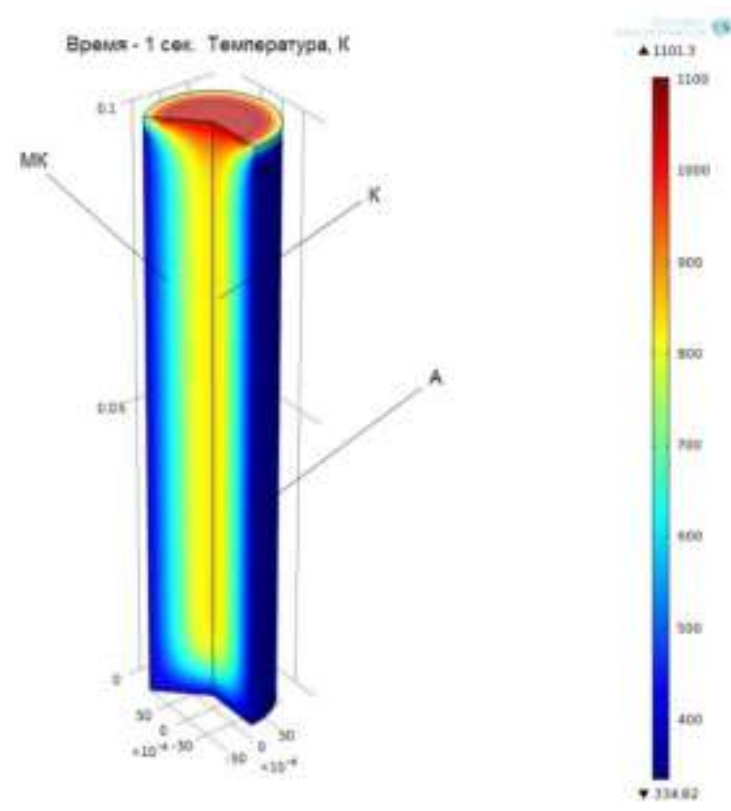

А - аморфна структура, МК - мікрокристалічна, К - кристалічна Рис. 9 - Температурне поле розплаву $\mathrm{Cu}_{45} \mathrm{Ti}_{35} \mathrm{Zr}_{20}$ в охолоджуваній формі 


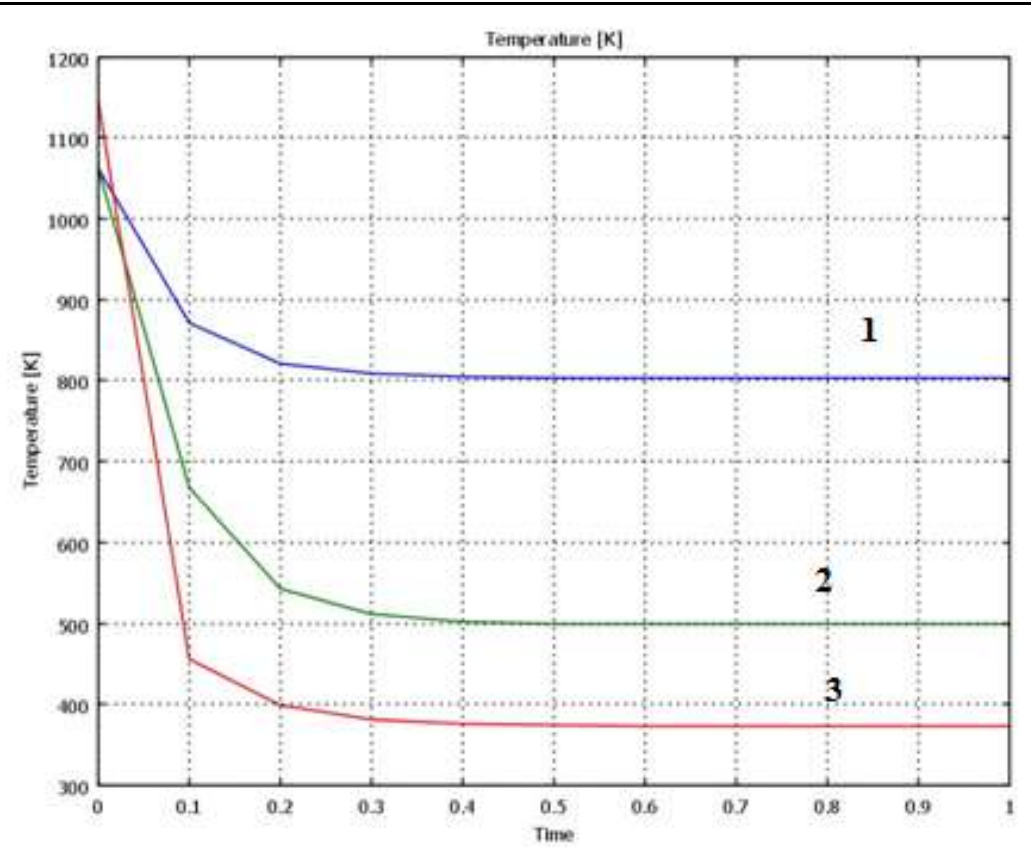

Рис.10 - Розподіл температури в сплаві $\mathrm{Cu}_{45} \mathrm{Ti}_{35} \mathrm{Zr}_{20}$ при температурі на стінках форми $373 \mathrm{~K}$

1 - центр литво, 2 - поблизу охолоджуваної стінки форми, 3 - поблизу кордону 3 охолоджувальним середовищем.

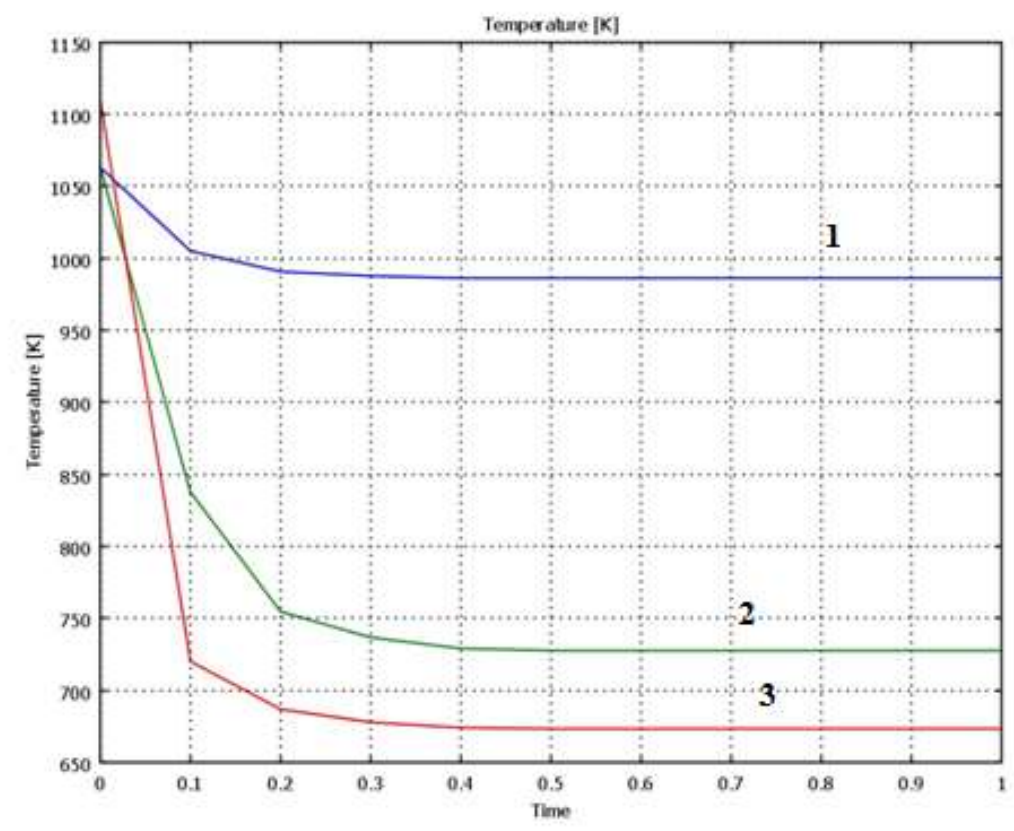

Рис.11 - Розподіл температури в сплаві $\mathrm{Cu}_{45} \mathrm{Ti}_{35} \mathrm{Zr}_{20}$ при температурі на стінках форми $673 \mathrm{~K}$

3 представлених графіків рис.6-8 видно, що в інтервалі 1 секунди відбувається надшвидке охолодження металу. Зіставляючи дані графіки можна зробити висновок про те, що формування аморфної структури (А) (рис.6) по всьому шару металу можливо тільки при максимальних швидкостях охолодження на стінках охолоджуваної форми рис.7. Решта графіки рис.9-11 свідчать про те, що зі зменшенням швидкості охолодження відбувається лише часткова аморфізація поблизу охолоджуваної стінки форми, що призводить до утворення як аморфної (А), так і кристалічної (К) структури (рис. 2-3). Ближче до центральної частини злитка в 


\section{Будівельні матеріали, конструкції та споруди}

результаті меншої тепловіддачі формується мікрокристалічна (МК) структура металу. У центральній частині злитка навіть при максимальній мірі охолодження формування аморфної структури не відбувається. Наявність конвективних потоків в середині злитка призводить до збільшення тепловіддачі і підвищення швидкості охолодження, внаслідок чого вдається досягти мікрокристалічної структури металу, 3 поліпшеними механічними властивостями.

Для сплаву $\mathrm{Cu}_{45} \mathrm{Ti}_{35} \mathrm{Zr}_{20}$ критична швидкість охолодження склала $10^{2}-10^{3} \mathrm{~K} / \mathrm{c}$ що дало можливість отримати 3 розплаву зразки 3 аморфною структурою, що підтверджується рентгеноструктурними дослідженнями. Створювані при такому загартуванні аморфно-кристалічні структури володіють хорошими механічними властивостями, твердість сплаву складає $750 \mathrm{HV}$.

\section{Висновки}

Максимальна степінь охолодження під час процесу лиття металу в форму, що охолоджується досягається у поверхонь шару, що примикають до охолоджуваних стінок форми. Температура кристалізації всередині шару вище, ніж у поверхонь шару.
Тривалість процесу охолодження всередині шару в 5-10 разів більше.

Отримані експериментальні та розрахункові дані показали, що при використанні методу лиття в охолоджувану форму для отримання аморфних виробів товщиною кілька міліметрів необхідні сплави 3 досить низькою критичною швидкістю охолодження, менше $1000 \mathrm{~K} / \mathrm{c}$. Отримання масивних аморфних зразків можливо при їх товщині до декількох міліметрів при застосуванні даного експериментального методу лиття.

Визначено два головних фактори, які обмежують товщину аморфних виробів: Зниження коефіцієнта тепловіддачі від розплаву до форм при збільшенні товщини виробів і локальна кристалізація розплаву, яка залежить від об'єму лиття і збільшується при наближенні товщини виробу до критичної.

Найбільший інтерес 3 досліджуваних нами сплавів представляють масивні аморфні сплави системи мідь-титанцирконій. Від інших масивних аморфних сплавів вони відрізняються високою твердістю, міцністю і термічною стабільністю. При збільшенні вмісту $\mathrm{Zr}$ до $18 \%$ термічна стабільність сплаву зростає 3 690К до 815 К, що істотно збільшує область застосування даного виду сплавів.

\section{Лiтература}

1. Pavlenko A.M., Usenko B.O., Koshlak H.V. Analysis of thermal peculiarities of alloying with special properties, Metallurgical and Mining Industry, 2014, No2, p.p. 15-20.

2. Pavlenko A.M., Usenko B.O., Koshlak H.V. Research the energyefficient process of high-speed casting of metal between the cooling rolls, Metallurgical and Mining Industry, 2014, No5, p.p. 68-72.

3. Pavlenko A.M., Usenko B.O., Koshlak H.V. Mathematical modeling of the casting process in Comsol 3.5a package, Metallurgical and Mining Industry, 2015, No1, p.p. 132-140.

Павленко Анатолій Михайлович, доктор технічних наук, професор, завідувач кафедри теплогазопостачання, вентиляиї̈ та теплоенергетики Полтавського національного технічного університету імені Юрія Кондратюка.

Тел.05322-7-38-57/e-mail: am.pavlenko@i.ual

Усенко Богдан Олегович, аспірант, кафедра теплогазопостачання, вентилячії та теплоенергетики, Полтавський національний технічний університет імені Юрія Кондратюка,

тел.05322-7-38-57, / e-mail assistant_pntu@ukr.net

Pavlenko Anatoliy, Doctor of Sciences, professor, Department of «Heat and gas supply, ventilation and heat power engineering», Poltava National Technical Yuri Kondratyuk University

Tel.05322-7-38-57e-mail am.pavlenko@i.ua.

Usenko Bohdan, postgraduate, Department of «Heat and gas supply, ventilation and heat power engineering», Poltava National Technical Yuri Kondratyuk University

Tel.05322-7-38-57, / e-mail assistant_pntu@ukr.net.

Стаття поступила 20.05.2015p. 